\title{
Jumping plant lice (Hemiptera, Psylloidea) in rest stops of Hungarian highways
}

\author{
Jenő Kontschán ${ }^{1 *}$ @e, Géza Ripka ${ }^{2}$ and Balázs Kiss ${ }^{1}$
}

\footnotetext{
${ }^{1}$ Plant Protection Institute, Centre for Agricultural Research, ELKH, H-1525, P.O. Box 102, Budapest, Hungary

${ }^{2}$ Directorate of Plant Protection, Soil Conservation and Agri-environment, National Food Chain Safety Office, H-1118, Budaörsi út 141-145, Budapest, Hungary
}

\section{RESEARCH ARTICLE}

Received: February 15, 2021 • Revised manuscript received: May 13, 2021 - Accepted: May 17, 2021

Published online: July 14, 2021

(c) 2021 The Author(s)

\begin{abstract}
In the framework of a survey of arthropods in rest stops of Hungarian highways, 19 species of jumping plant lice were collected. Three species belong to the family Aphalaridae, one to Calophyidae, two to Liviidae, nine to Psyllidae and four to Triozidae. Two species (Livilla variegata and Trioza neglecta) are alien, non-indigenous species; the others are native to Hungary. The most abundant species were Calophya rhois, Cacopsylla melanoneura and Trioza neglecta. The specimens of C. melanoneura were found in 20, T. neglecta in 10 and C. rhois in 6 localities out of the 31 rest stops surveyed.
\end{abstract}

\section{KEYWORDS}

psyllids, motorway, distribution/faunistics, Hungary

\section{INTRODUCTION}

The eminent role of roads and highways in the expansion of introduced species is well known (Čamprag, 2002; Fokin, 2006; Gilbert et al., 2004; Horváth and Benedek, 1986). Invasive pests can be transported for several hundreds of kilometres from their original habitats by vehicles to

\footnotetext{
*Corresponding author. E-mail: kontschan.jeno@atk.hu
} 
colonise far and new habitats. On the other hand, protective zones of highways can also be considered as green corridors in agricultural landscapes and these corridors may serve also as refuges for native insects. In the last few years numerous papers have been published on the invertebrates inhabiting highway rest stops in Hungary, including also discoveries of several new alien and invasive agricultural pests (e.g. Basky, 2015; Bayoumy et al., 2011; Kiss et al., 2013, 2016; Kontschán and Kiss, 2015; Kontschán et al., 2015; Kozár, 2009; Kozár et al., 2013; Lengyel et al., 2015; Podlussány et al., 2014; Szentesi et al., 2017; Vona-Túri et al., 2017, 2019).

The jumping plant lice or psyllids (Hemiptera, Psylloidea) are a group of phytophagous insects with numerous economically important and invasive species. So far more than 70 jumping plant louse species have been reported from Hungary (Kontschán and Ripka, 2020), but several species have been found only rarely or were recorded only at the end of the 19th century (Ripka, 2008). A systematic survey of the insect fauna in rest stops (service areas) of Hungarian highways was carried out in the 2010s to evaluate the importance of these habitats in the spread of invasive species. Jumping plant lice were not a focal group of the study; however, numerous specimens of the superfamily were collected. These records are summarized in the present work.

\section{MATERIAL AND METHODS}

The faunistic survey was organized on 31 rest stops of five highways in Hungary (Fig. 1). The rest stops formed two transects in the country (M1, M3, M5, M7) and a half-circle (M0) around the capital, Budapest. Adult jumping plant lice were collected by two methods: branch-beating and

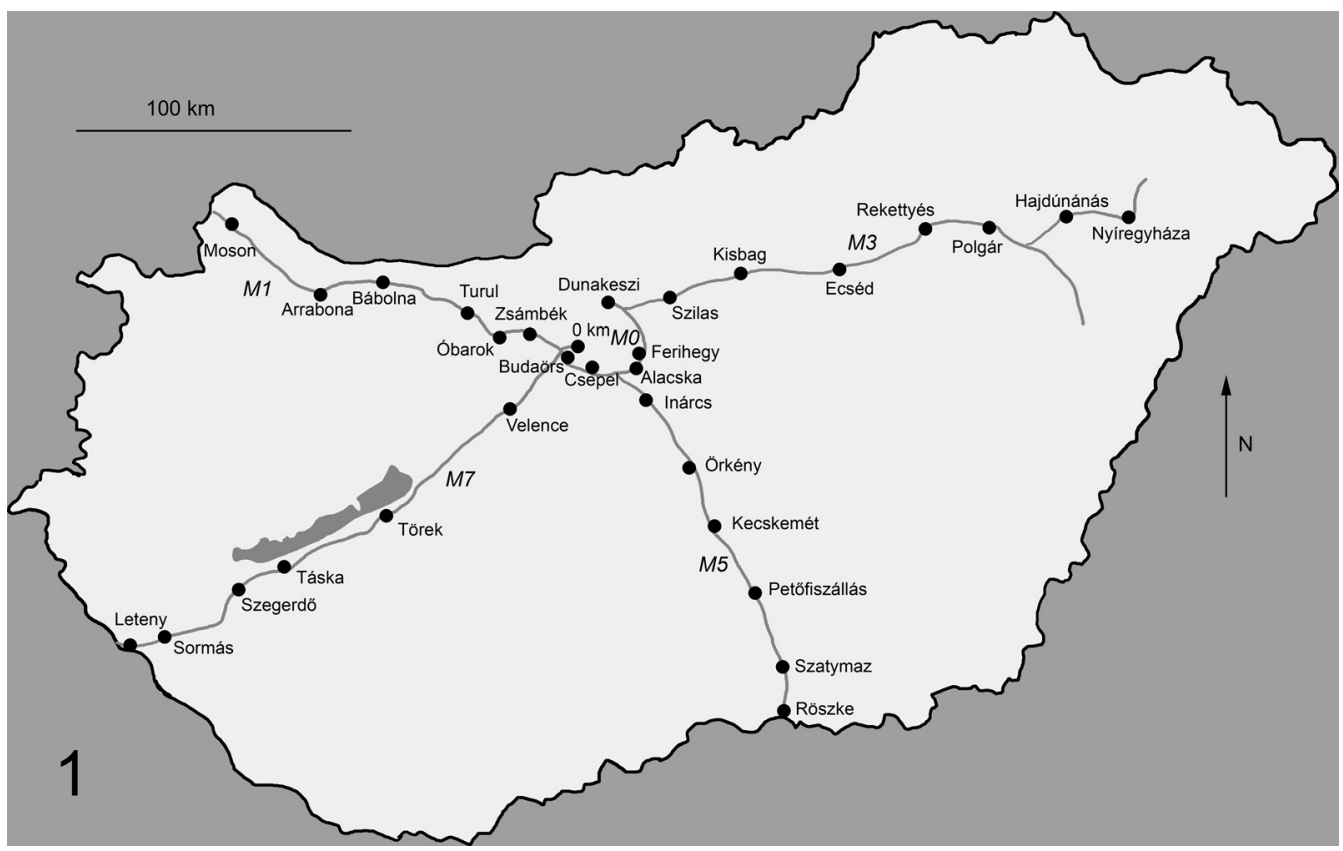

Fig. 1. The collection sites on the highways in Hungary 
suction sampling. In the case of the branch-beating method, 20 branches of five plant species were beaten in each rest stops with a stick and falling insects were collected into a large umbrella, thus the plant species from which the specimens were collected were known. The suction sampling was carried out using a hand-hold leaf blower (see Samu and Sárospataki, 1995), referred to in the followings as D-VAC. In this case, samples were taken from leaf litter and sward, and the source plants were not identified. The collected insect material was transferred into plastic bags, stored in a deep freezer, later sorted into different insect groups and the specimens were preserved in $75 \%$ alcohol. For identification, we used books of Ossiannilsson (1992) and Hodkinson and Hollis (1987), and the presented system followed Burckhardt et al. (2021). The jumping plant lice were cleared in hot lactic acid and examined on a cavity slide under a compound microscope. After identification, the specimens were placed back in alcohol and deposited in the Plant Protection Institute, Centre for Agricultural Research, Budapest, Hungary.

\section{RESULTS}

Altogether 19 species of jumping plant lice were collected in the study. The species belonged to five families, Aphalaridae, Calophyidae, Liviidae, Psyllidae and Triozidae. The highest number of species were found along the highway M3 (10 species), eight species were collected on M1, seven on M7, six on M0 and only three on M5. There were important differences among the species numbers in the rest stops. Only one species was collected at the majority of the collection sites, and the highest species number per site was five (Fig. 2).

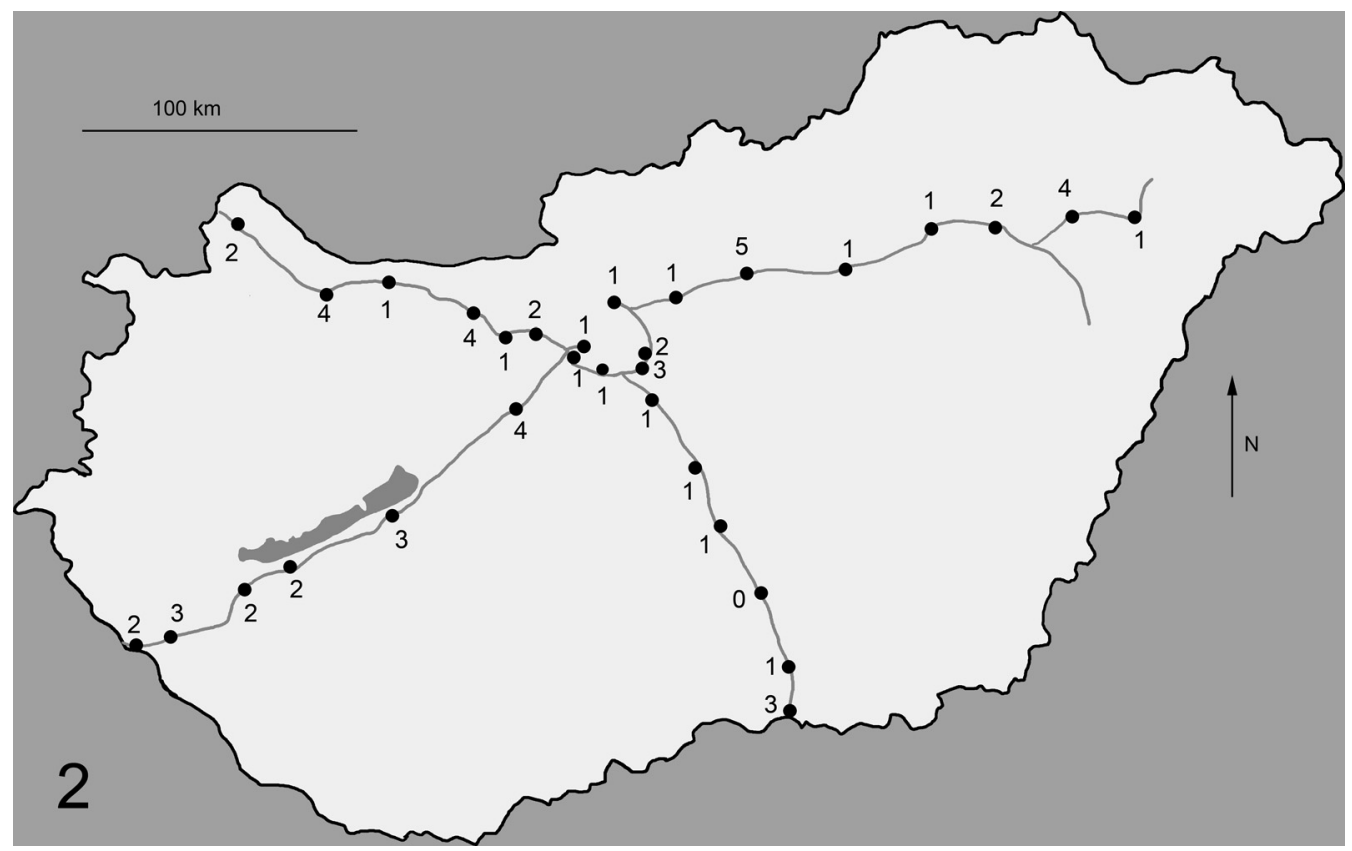

Fig. 2. The numbers of the species of Psylloidea recorded on the highway rest stops 


\section{List of the species}

\section{APHALARIDAE}

Aphalara maculipennis Löw, 1886 (Fig. 3)

Localities: M3, Hajdúnánás, DVAC, 19.V.2012.

Craspedolepta flavipennis (Foerster, 1848) (Fig. 3)

Localities: M3, Polgár, DVAC, 19.V.2012.

Rhinocola aceris (Linnaeus, 1758) (Fig. 3)

Localities: M0, Ferihegy, Celtis occidentalis, 24.V.2013; M3, Kisbag, Acer campestre, Crataegus monogyna, Euonymus verrucosus, Quercus cerris, 30.V.2013; M3, Kisbag, Acer campestre, Crataegus monogyna, Euonymus verrucosus, Quercus cerris, 17.VII.2013.

\section{CALOPHYIDAE}

\section{Calophya rhois (Löw, 1877) (Fig. 4)}

Localities: M1, Turul, DVAC, 16.V.2012; M1, Turul, Thuja plicata, 18.VII.2013; M0, Alacska, Salix alba, 19.VII.2013; M3, Ecséd, Cotinus coggygria, 17.VII.2013.; M3 Ecséd Juniperus communis, 17.VII.2013.; M3, Ecséd, Cotinus coggygria, 30.V.2013.; M3, Ecséd, Forsythia sp. 30.V.2013.; M3, Ecséd, Ligustrum vulgare, 30.V.2013.; M3, Ecséd, Hibiscus sp., 30.V.2013.; M3, Ecséd, Cotinus coggygria, 30.V.2013.; M3, Ecséd, Ligustrum vulgare, 17.VII.2013.; M3, Ecséd, Forsythia sp., 17.VII.2013.; M3, Ecséd, Cotoneaster sp., 17.VII.2013.; M3 Ecséd Cotinus coggygria, 24.IX.2013.; M3, Ecséd, Ligustrum vulgare, 24.IX.2013.; M3, Kisbag, Euonymus sp., 30.V.2013.; M3, Kisbag,

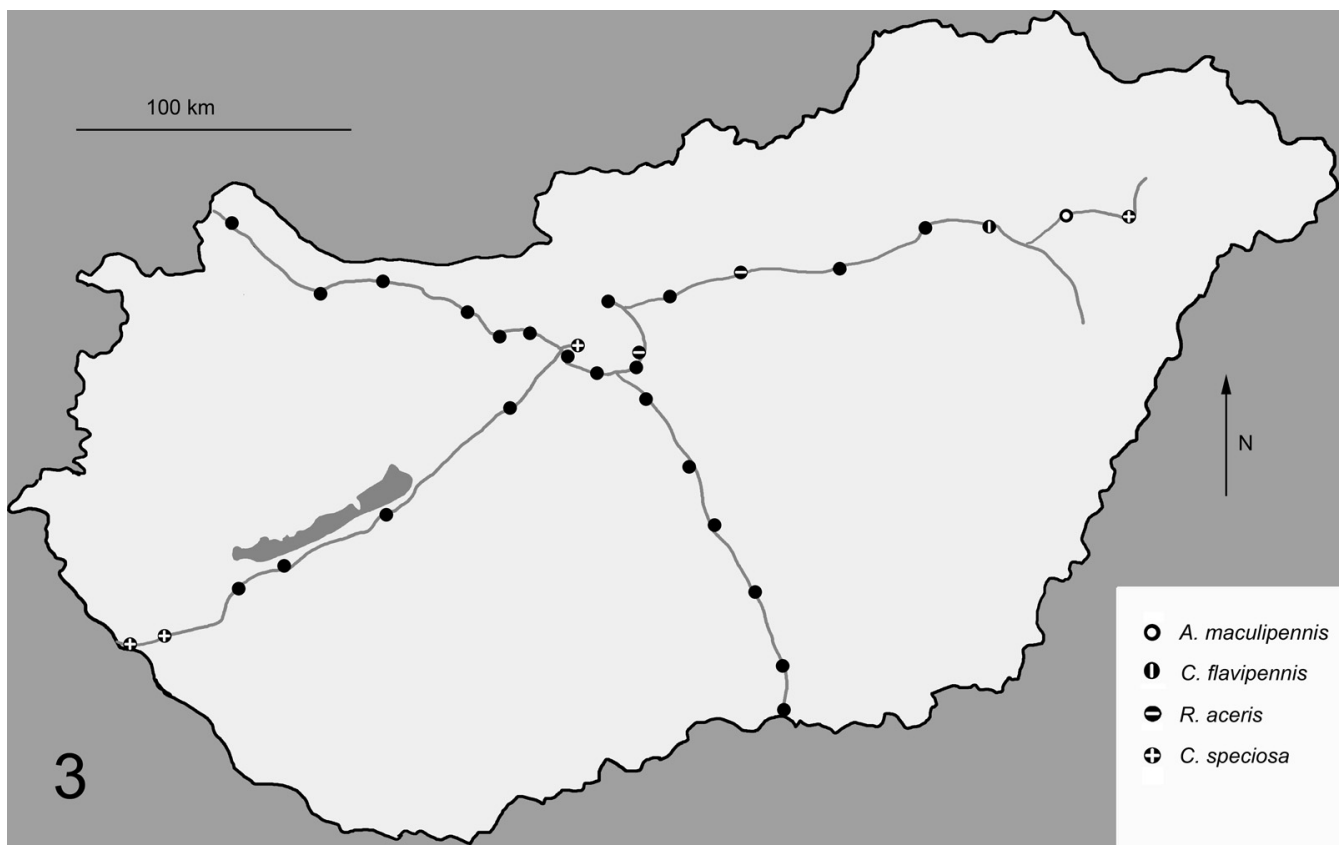

Fig. 3. Distribution of species from the families Aphalaridae and Liviidae on the highways 


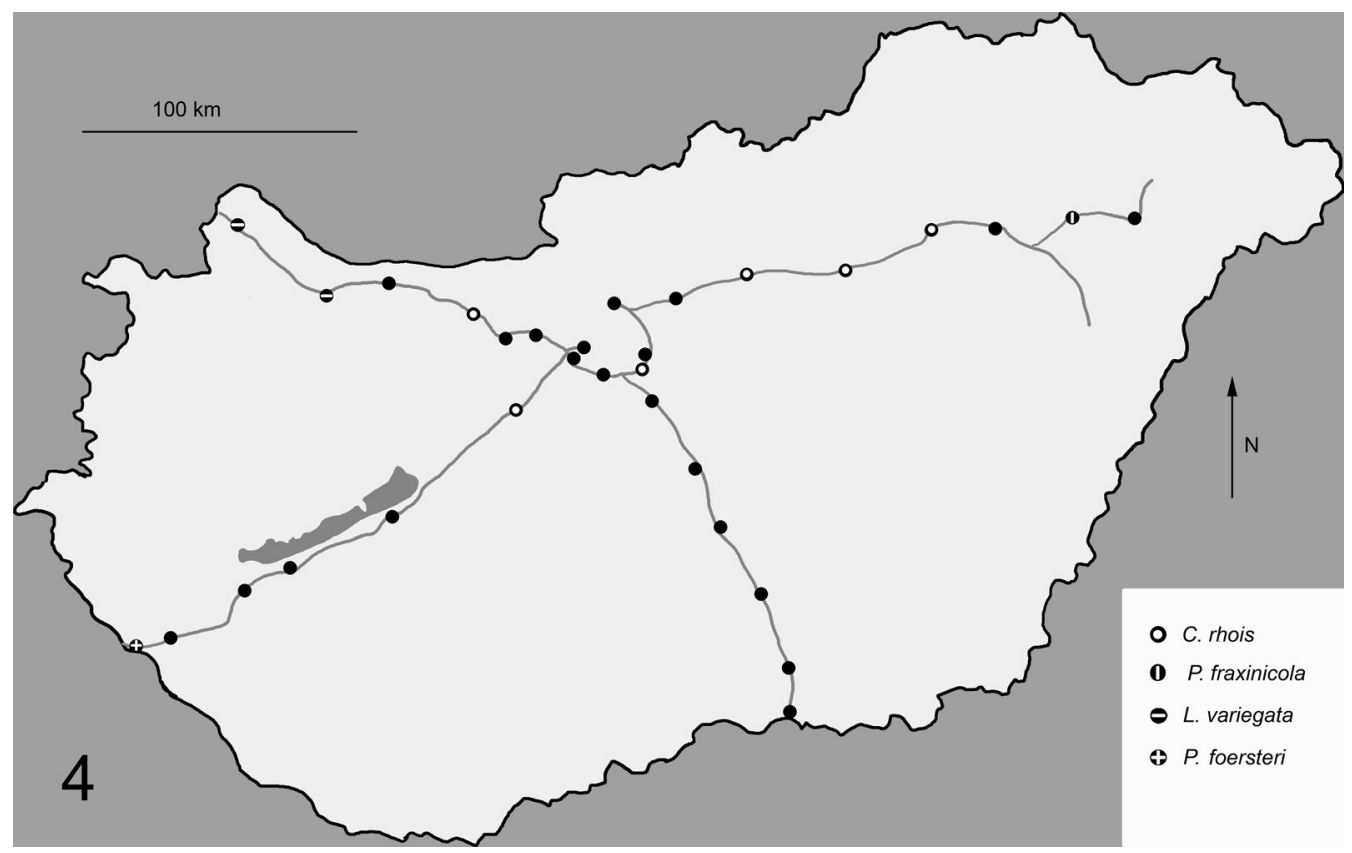

Fig. 4. Distribution of species from the families Calophyidae, Liviidae and Psyllidae on the highways

Crataegus monogyna, 30.V.2013.; M3, Kisbag, Elaeagnus angustifolia, 30.V.2013.; M3, Kisbag, Euonymus verrucosus, 17.VII.2013.; M3, Rekettyés, Spiraea sp., 17.VII.2013.; M3, Rekettyés, Pyracantha coccinea, 17.VII.2013.; M3, Rekettyés, Pyracantha coccinea, 24.IX.2013.; M3, Rekettyés, Tamarix sp., 24.IX.2013.; M3, Rekettyés, Spiraea sp., 24.IX.2013.; M3, Rekettyés, Cotinus coggygria, 24.IX.2013.; M3, Rekettyés, Pyracantha coccinea, 24.IX.2013.; M3, Rekettyés, Tamarix sp., 24.IX.2013.; M3, Rekettyés, DVAC, 24.IX.2013.; M7, Velence, Pyrus pyraster, 15.VII.2013.; M7, Velence, Prunus mahaleb, 15.VII.2013.; M7, Velence, Tilia cordata, 15.VII.2013.0.5

\section{LIVIIDAE}

Camarotoscena speciosa (Flor, 1861) (Fig. 3)

Localities: M0, SOS 0km, Corylus avellana, 25.IX.2013.; M3 Nyíregyháza, Euonymus verrucosus, 7.VII.2013.; M7, Letenye, Populus euramericana, 15.VII.2013.; M7, Letenye, Thuja plicata, 15.VII.2013; M7, Sormás, Elaeagnus angustifolia, 15.VII.2013.

Psyllopsis fraxinicola (Foerster, 1848) (Fig. 4)

Localities: M3, Hajdúnánás, Fraxinus angustifolia, 17.VII.2013.

\section{PSYLLIDAE}

Cacopsylla bidens (Šulc, 1907) (Fig. 5)

Localities: M1, Turul, DVAC, 16.V.2012.; M0, Alacska, Pyrus sp., 5:V.2013.; M7, Velence, Pyrus sp., 02.VI.2020.

Cacopsylla melanoneura (Foerster, 1848) (Fig. 5) 


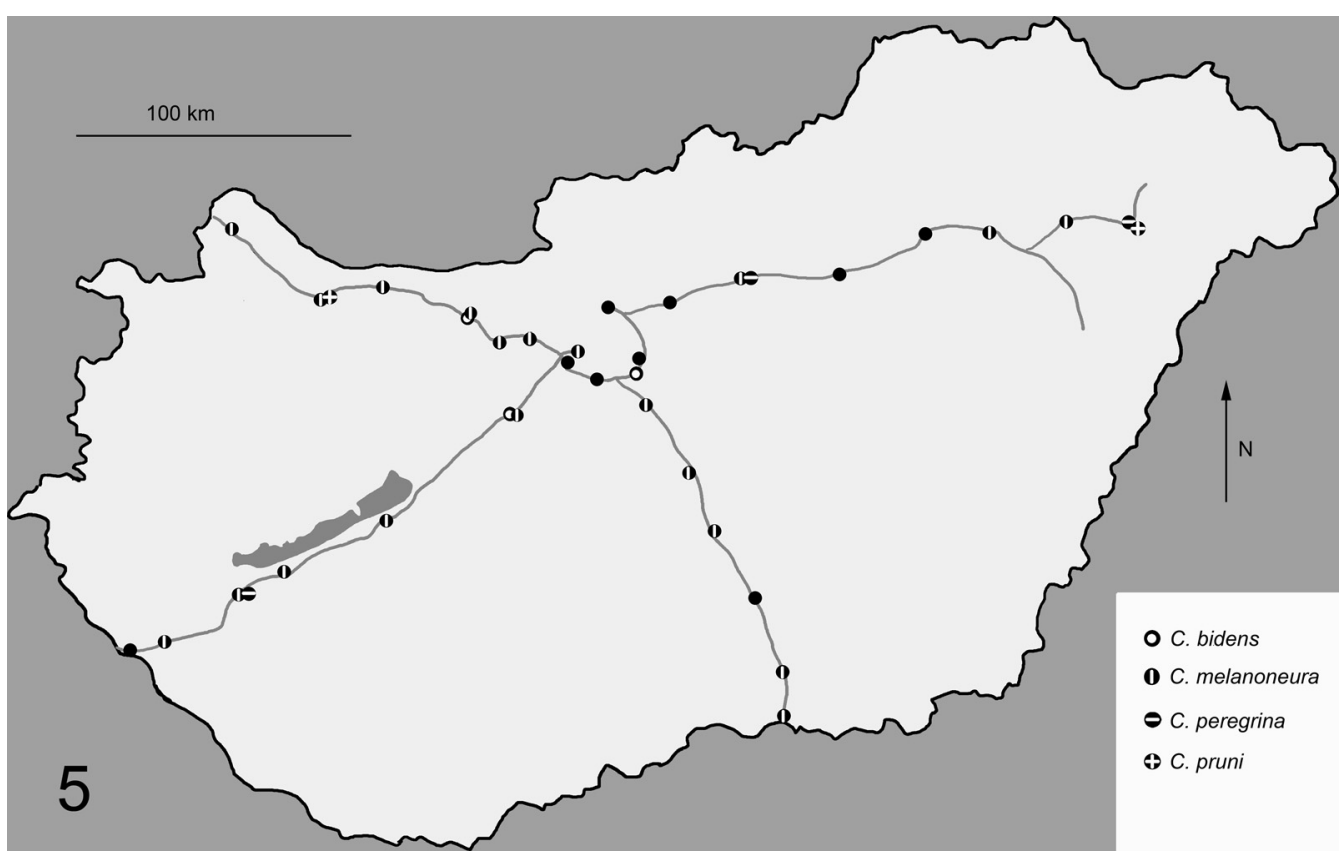

Fig. 5. Distribution of species from the family Psyllidae on the highways I

Localities: M0, 0 km, SOS, DVAC, 24.V.2013.; M0, 0 km, SOS, Prunus cerasifera f. atropurpurea, 18.V.2013.; M0, 0 km, SOS, DVAC, Quercus robur, 18.V.2013.; M0, 0 km, SOS, Prunus cerasifera f. atropurpurea, 24.V.2013.; M0, 0 km, SOS, kop, Corylus avellana, 24.V.2013.; M1, Arrabona DVAC, 16.V.2012.; M1, Arrabona DVAC, 23.VII.2013.; M1, Arrabona, Crataegus sp., 23.V.2013.; M1, Arrabona, Ligustrum vulgare, 23.V.2013.; M1, Arrabona, Tilia platyphyllos, 23.V.2013.; M1, Arrabona, Viburnum opulus, 23.V.2013.; M1, Arrabona, Prunus cerasifera f. atropurpurea, 23.V.2013.; M1, Bábolna, DVAC, 16.V.2012.; M1, Bábolna, Spiraea sp. 23.V.2013.; M1, Bábolna, Picea abies, 23.V.2013.; M1 Bábolna, Cornus sanguinea, 23.V.2013.; M1, Moson DVAC, 23.V.2013.; M1, Moson, Rosa canina, 23.V.2013.; M1, Moson, Robinia pseudoacacia, 23.V.2013.; M1, Moson, Pinus nigra, 23.V.2013.; M1, Óbarokk DVAC, 23.V.2013.; M1, Óbarokk, Pinus nigra, 23.V.2013.; M1, Óbarokk, Picea abies, 23.V.2013.; M1, Turul DVAC, 16.V.2012.; M1, Turul, Crataegus sp., 23.V.2013.; M1, Zsámbék DVAC, 16.V.2012.; M1, Zsámbék, unknown plant, 23.V.2013.;M3, Hajdúnánás, Pyrus pyraster, 30.V.2013.; M3, Kisbag, DVAC, 23.V.2013.; M3, Kisbag, Crataegus monogyna, 30.V.2013.; M3, Kisbag, Quercus cerris, 30.V.2013.; M3, Polgár, Euonymus sp., 30.V.2013.; M5, Inárcs DVAC, 15.V.2013.; M5, Inárcs, Pinus nigra, 21.V.2013.; M5, Inárcs, Crataegus monogyna, 21.V.2013.; M5, Inárcs, Robinia pseudoacacia, 21.V.2013.; M5, Kecskemét, Pyracantha coccinea, 21.V.2013.; M5, Örkény, Juniperus virginiana, 21.V.2013.; M5, Röszke, Celtis occidentalis, 21.V.2013.; M5, Röszke, Spiraea sp. 21.V.2013.; M5, Röszke, Tamarix sp., 21.V.2013.; M5, Szatymaz, Acer campestre, 21.V.2013.; M7, Sormás, DVAC, 14.V.2012.; M7, Szegerdő, DVAC, 14.V.2012.; M7, Táska, DVAC, 5 14.V.2012.; M7, Táska, Symphoricarpos sp., 10.VI.2013.; Törek, DVAC, 14.V.2012.; M7, Velence, DVAC, 14.V.2012.; M7, Velence, Fraxinus sp., 02.VI.2020. 


\section{Cacopsylla peregrina (Foerster, 1848) (Fig. 5)}

Localities: M3, Kisbag, Crataegus monogyna, 17.VII.2013.; M3, Nyíregyháza, unknown host, 06.VI.2020; M7, Szegerdő, Crataegus sp., 02.VI.2020.

Cacopsylla pruni (Scopoli, 1763) (Fig. 5)

Localities: M1, Arrabona, Prunus cerasifera f. atropurpurea, 23.V.2013.; M3 Nyíregyháza, unknown host, 06.VI.2020.

Cacopsylla pyri (Linnaeus, 1761) (Fig. 6)

Localities: M0, Alacska, Acer platanoides, 24.V.2013.; M0, Alacska, Pyrus sp. 24.V.2013.; M3, Hajdúnánás, Pyrus sp., 7.VII.2013.

Cacopsylla pyrisuga (Foerster, 1848) (Fig. 6)

Localities: M3, Hajdúnánás, Pyrus sp., 23.IV.2020.

Cacopsylla saliceti (Foerster, 1848) (Fig. 6)

Localities: M5, Röszke, Salix alba, 21.V.2013.; M7, Szegerdő DVAC, 14.V.2012.; M7, Táska DVAC, 14.V.2012.; M7, Táska, Salix sp., 02.VI.2020; M7, Törek DVAC, 14.V.2012.; M7, Velence, Tilia platyphyllos, 10.VI.2013.

Livilla variegata (Löw, 1881) (Fig. 4)

Localities: M1, Arrabona, Crataegus sp., 23.V.2013.; M1, Arrabona, Ligustrum vulgare, 23.V.2013.; M1, Moson, Robinia pseudoacacia, 23.V.2013.

Psylla foersteri Flor, 1861 (Fig. 4)

Localities: M7, Letenye, Alnus glutinosa, 15.VII.2013.; M7, Letenye, Alnus glutinosa, 02.VI.2020.

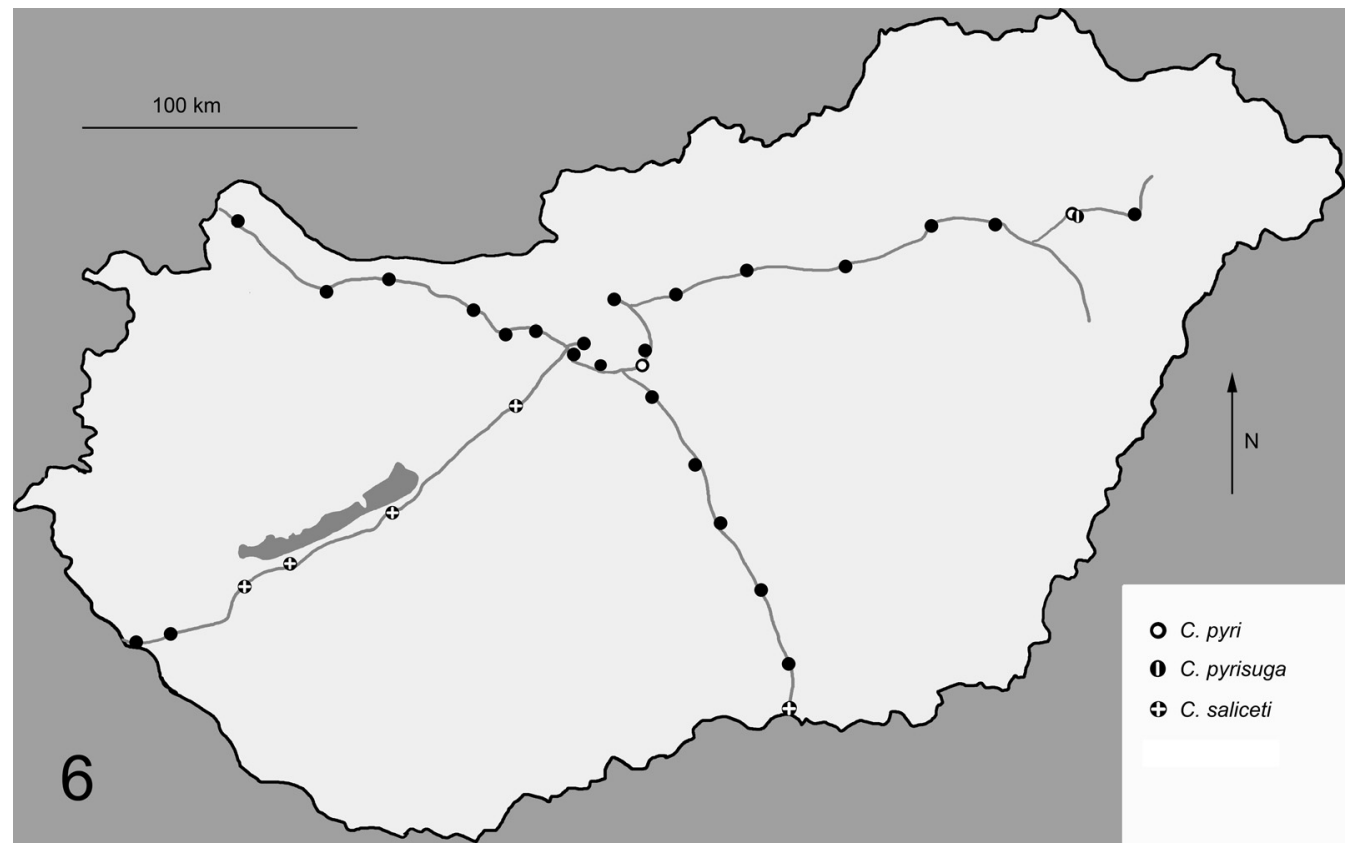

Fig. 6. Distribution of species from the family Psyllidae on the highways II 


\section{TRIOZIDAE}

\section{Bactericera albiventris (Foerster, 1848) (Fig. 7)}

Localities: M1, Arrabona, Salix alba, 18.VII.2013.; M5, Röszke, Salix alba, 18.IX.2013.; M5, Röszke, Salix alba, 16.IX.2013.

Trioza galii Foerster, 1848 (Fig. 7)

Localities: M7 Sormás, Quercus robur, 16.IX.2013.

Trioza neglecta Loginova, 1978 (Fig. 7)

Localities: M0, Csepel, Fraxinus ornus, 25.IX.2013.; M0, Dunakeszi, Elaeagnus angustifolia, 19.VII.2013.; M0, Dunakeszi, Hippophae rhamnoides, 25.IX.2013.; M0, Ferihegy, Elaeagnus angustifolia, 24.V.2013.; M0, Ferihegy, Elaeagnus angustifolia, 19.VII.2013.; M0, Ferihegy, Elaeagnus angustifolia, 25.IX.2013.; M1, Turul, Elaeagnus angustifolia, 20.IX.2013.; M1, Turul, Crataegus sp., 20.IX.2013.; M1, Zsámbék, Elaeagnus angustifolia, 18.VII.2013.; M3, Kisbag, Elaeagnus angustifolia, 24.IX.2013.; M3, Szilas, Elaeagnus angustifolia, 19.VII.2013.; M3, Szilas, Elaeagnus angustifolia, 24.IX.2013.; M7, Budaörs, Thuja plicata, 15.VII.2013.; M7, Budaörs, Tamarix sp. 15.VII.2013.; M7, Budaörs, Tamarix sp., 16.IX.2013.; M7, Budaörs, Populus euramericana/nigra, 15.VII.2013.; M7, Budaörs, Hippophae rhamnoides, 15.VII.2013.; M7, Budaörs, Hippophae rhamnoides, 16.IX.2013.; M7, Budaörs, Tilia cordata, 15.VII.2013.; M7, Budaörs, Tilia cordata, 16.IX.2013.; M7, Budaörs, Thuja occidentalis, 16.IX.2013.; M7, Törek, Elaeagnus angustifolia, 16.IX.2013.; M7, Velence, Elaeagnus angustifolia, 15.VII.2013.; M7, Velence, Elaeagnus angustifolia, 10.VI.2013.

Trioza urticae (Linnaeus, 1758) (Fig. 7)

Localities: M7, Letenye, Galium sp., 02.VI.2020; Letenye, Urtica dioica, 02.VI.2020.

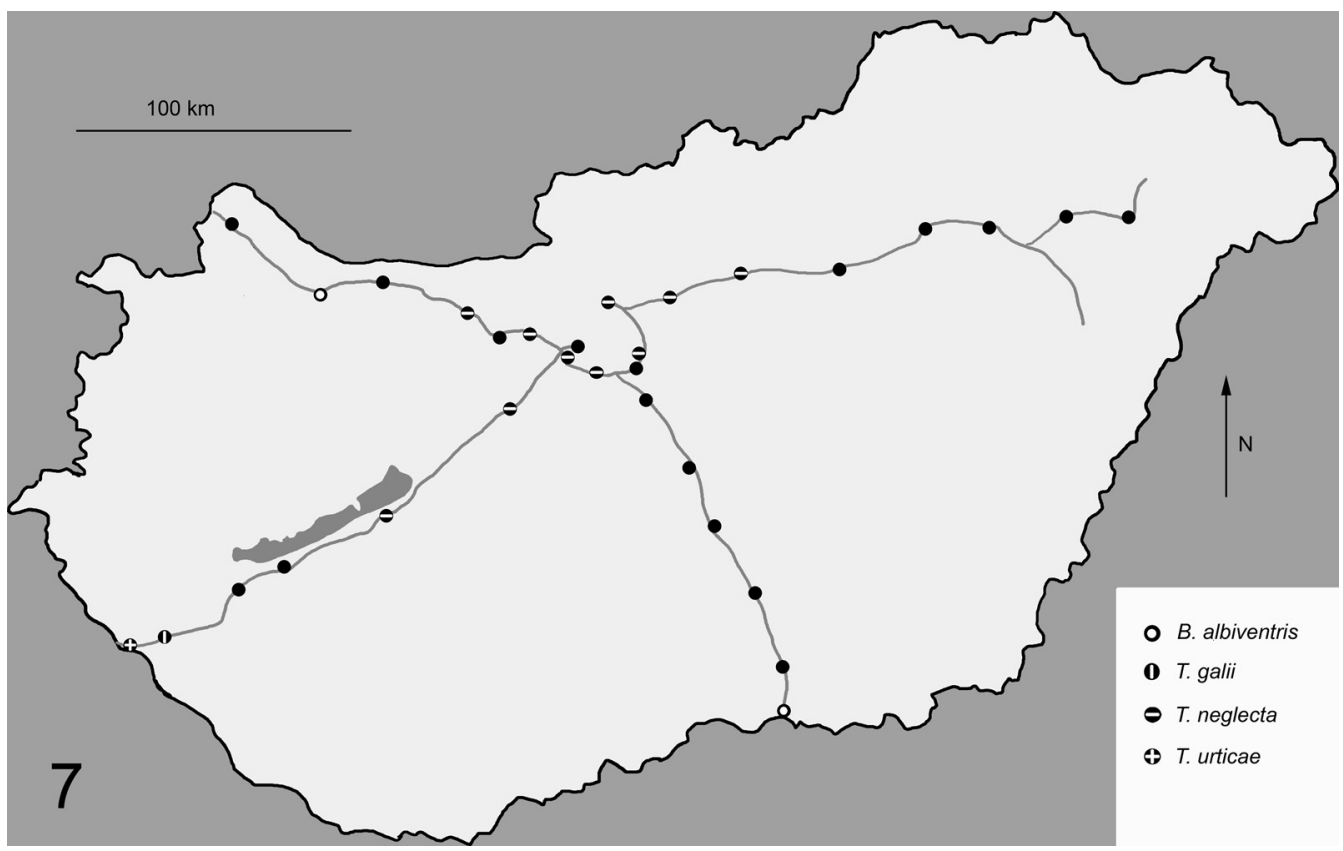

Fig. 7. Distribution of species from the family Triozidae on the highways 


\section{DISCUSSION}

In the framework of our survey on Hungarian highways, 19 species of jumping plant lice were collected. Three of them belong to family Aphalaridae, one to Calophyidae, two to Liviidae, nine to Psyllidae and four to Triozidae. Two species (Livilla variegata and Trioza neglecta) are alien, non-indigenous species, while all the others are native to Hungary (Ripka, 2008). Regarding the species numbers of the psylloid families of Hungary (Ripka, 2008), the triozids with four reported species seem to be underrepresented compared with the other families.

Jumping plant lice were collected at 30 localities from the 31 sites surveyed in total. Cacopsylla melanoneura, oligophagous mainly on Crataegus and Malus spp., was the most frequent species in the highway rest areas; it was found in 20 localities and was collected on more than 20 different plant species, most of which represented shelter or casual plants, not the host plants (according to the definition by Burckhardt et al., 2014). This species is very common in Hungary (Ripka, 2008; Kontschán et al., 2020). The alien T. neglecta, monophagous on Elaeagnus angustifolia, was found at 10 sites. Beside its host plant, this jumping plant louse was collected on eight other plant species. The host plants of T. neglecta are frequently planted in the rest stops, which is one of the reasons for its numerous occurrences. In contrast with the frequent occurrences in the highway rest stops, this species has been only rarely collected in Hungary before (Kontschán et al., 2020). Calophya rhois, monophagous on the smoke tree or smoke bush (Cotinus coggygria), was collected at six sites in the framework of the study. Beside its known host plant, $C$. rhois was also found on 10 other plant species, which should be considered as casual records; C. rhois generally reaches high abundances on its host, and its dispersing adults can be caught also on plants in close vicinity. The smoke tree is frequently planted in highway verges and rest stops, which explains the widespread occurrence of $C$. rhois at the surveyed sites. Widespread in the Mediterranean, C. rhois is considered as a native species also in Hungary, similarly to smoke tree, which can be found in natural environments in the mountainous area of the country (Kontschán et al., 2020). It should be noticed that C. rhois was mentioned as an alien species for Serbia (Jerinić-Prodanović, 2012), but this probably reflects only a different use of terminology, and the status of the species is perhaps identical in the two neighboring countries. The other jumping plant louse species were usually collected less frequently, at 1-5 different sites.

Noteworthy are also the records of another introduced species, Livilla variegata, monophagous on Laburnum spp., which was collected at two sites, where its known host plants were not recorded. Maybe this species arrived from the outside area of investigated rest stops of the highways and it was only a transient guest species in these habitats. This species has been scarcely found in Hungary, recorded only from Budapest (Ripka, 2008).

Three species with well-known economic importance (Cacopsylla pruni, C. pyri and C. pyrisuga) were also found at the rest stops of the highways, but in a very small number of specimens (1-2) and only at some localities (Figs 5-6), although their host plants (pear trees and blackthorn) are frequent native plants, planted also on the rest stops and in their surroundings.

Our study highlights the fact that psyllids have been only poorly studied in Hungary. Several species only scarcely recorded in the literature can be frequently found during systematic surveys even in artificial habitats, like highway verges. 


\section{ACKNOWLEDGEMENTS}

This study was supported by the projects NKFI-1 K128838 and NKFI-6 K91104.

\section{REFERENCES}

Basky, Zs. (2015). Aphid species colonizing conifer, juniper and cedar trees along Hungarian motorways. Acta Phytopathologica et Entomologica Hungarica, 50(2): 275-284.

Bayoumy, M. H., Fetykó, K., Tóbiás, I., Konczné Benedicty, Zs., Szita, É. and Kozár, F. (2011). A geographical study on Pseudaulacaspis pentagona and its parasitoids in Hungarian highways using pheromone traps and molecular markers. Entomologica Hellenica, 20: 3-17.

Burckhardt, D., Ouvrard, D., Queiroz, D. and Percy, D. (2014). Psyllid host-plants (Hemiptera: Psylloidea): resolving a semantic problem. Florida Entomologist, 97(1): 242-246.

Burckhardt, D., Ouvrard, D. and Percy, D.M. (2021). An updated classification of the jumping plant-lice (Hemiptera: Psylloidea) integrating molecular and morphological evidence. European Journal of Taxonomy, 736: 137-182.

Čamprag, D. (2002). Krajem XX veka - skakavci se ponovo masovno javljaju u Evropi i Aziji. Biljni lekar, 30: $114-122$.

Fokin, A. V. (2006). Urovni vredonosnosti zapadnogo kukuruznogo zhuka Diabrotica virgifera virgifera Le Conte. Vestnik zaschity rasteniy, 1: 61-62.

Gilbert, M. J., Grégorie, C., Freise, J. F. and Heitland, W. (2004). Long-distance dispersal and human population density allow the prediction of invasive patterns in the horse chesnut leafminer Cameraria ohridella. Journal of Animal Ecology, 5: 459-468.

Hodkinson, I. D. and Hollis, D. (1987). The legume-feeding psyllids (Homoptera) of the west Palaearctic region. Bulletin of the British Museum (Natural History). Entomology, 56: 1-86.

Horváth, B. and Benedek, P. (1986). A vadgesztenye-aknázómoly (Cameraria ohridella Deschka and Dimic 1986) Európában. [Cameraria ohridella Deschka and Dimic 1986 in Europe.] (in Hungarian). Acta Agronomica Óváriensis, 48: 183-228.

Jerinić-Prodanović, D. (2012). Alien species of jumping plant lice (Hemiptera: Psylloidea) in Serbia. Proceedings of the International Symposium on Current Trends in Plant Protection, Belgrade, Serbia, 25-28th September, 2012. Institute for Plant Protection and Environment Belgrade Serbia, pp. 553-560.

Kiss, B., Karap, A. K., Kis, A. and Szita, É. (2013). Az amerikai lepkekabóca (Metcalfa pruinosa) and a tujakabóca (Liguropia juniperi) előfordulása hazai autópálya pihenőhelyeken. [Occurrence of Metcalfa pruinosa and Liguropia juniperi in rest areas along Hungarian highways.] (in Hungarian) Növényvédelem, 49: 571-575.

Kiss, B., Kis, A. and Kákai, Á. (2016). The rapid invasion of spotted wing drosophila, Drosophila suzukii (Matsumura) (Diptera: Drosophilidae), in Hungary. Phytoparasitica, 44: 429-433.

Kontschán, J., Ács A., Suták, A. and Kiss, B. (2015). A hazai autópályák pihenőinek atkái (Akarológiai tanulmányok 4.) [Mites of the rest stops of the Hungarian highways (Akarológiai tanulmányok 4.)] (in Hungarian). StormingBrain kiadó, Budapest, pp. 1-124.

Kontschán, J. and Kiss, B. (2015). First record of the family Protodinychidae Evans, 1957 (Acari: Mesostigmata: Uropodina) from Hungary. Ecologica Montenegrina, 2(4): 283-288. 
Kontschán, J., Kiss, E. and Ripka, G. (2020). Új adatok a hazai levélbolhák (Insecta: Psylloidea) előfordulásaihoz. [New data to occurrences of the Hungarian jumping plant lice (Insecta: Psylloidea).] (in Hungarian) Növényvédelem, 81(5): 197-202.

Kontschán, J. and Ripka, G. (2020). A seprüzanót-levélbolha [Arytaina genistae (Latreille, 1804)] első előkerülése hazánkból. [First record of broom psyllid [Arytaina genistae (Latreille, 1804)] in Hungary (Hemiptera: Psylloidea)] (in Hungarian) Növényvédelem, 81(10): 4563-5456.

Kozár, F. (2009). Pajzstetü (Hemiptera: Coccoidea) fajok és a klímaváltozás: vizsgálatok Magyarországi autópályákon. [Scale species (Hemiptera, Coccidea) and climate change studies on Hungarian highways.] (in Hungarian) Növényvédelem, 45: 577-588.

Kozár, F., Szita, É., Fetykó, K., Neidert, D., Konczné Benedicty, Zs. és Kiss, B. (2013). Pajzstetvek, sztrádák, klíma. [Scale insects, highways, climate.] (in Hungarian) MTA ATK Növényvédelmi Intézet, Budapest. pp. 216.

Lengyel, G. D., Orosz, Sz., Kiss, B. and Kárpáti, Zs. (2015). New records and present status of the invasive spotted wing Drosophila, Drosophila suzukii Matsumura (Diptera) in Hungary. Acta Zoologica Academiae Scientiarum Hungaricae, 61(1): 73-80.

Ossiannilsson, F. (1992). Psylloidea (Homoptera) of Fennoscandia and Denmark. Fauna Entomologica Scandinavica, vol. 26. Brill, 346 pp.

Podlussány, A., Szita, É., Lupták, R., Szénási, V. and Kiss, B. (2014). Four weevil species new to the fauna of Hungary from motorway rest areas (Coleoptera: Curculionidae). Folia Entomologica Hungarica, 75: 7378.

Ripka, G. (2008). Checklist of the Psylloidea of Hungary (Hemiptera: Sternorrhyncha). Acta Phytopathologica et Entomologica Hungarica, 43: 121-142.

Samu, F. and Sárospataki, M. (1995). Design and use of a hand-hold suction sampler, and its comparison with sweep net and pifall trap sampling. Folia Entomologica Hungarica, 56: 195-203.

Szentesi, Á., György, Z., Jermy, T. and Kiss, B. (2017). Seasonal changes in bruchid (Coleoptera: Chrysomelidae: Bruchinae) assemblages along managed highway ecotones. European Journal of Entomology, 114: 488-499.

Vona-Túri, D., Szmatona-Túri, T. and Kiss, B. (2017). Effects of roads and adjacent areas on diversity of terrestrial isopods of Hungarian highway verges. Biologia, Bratislava, 72: 1486-1493.

Vona-Túri, D., Szmatona-Túri, T., Weiperth, A. and Kiss, B. (2019). Diversity and abundance of Isopods (Isopoda: Oniscidea) on Hungarian highway verges. Acta Zoologica Bulgarica, 71(3): 385-398.

Open Access. This is an open-access article distributed under the terms of the Creative Commons Attribution 4.0 International License (https://creativecommons.org/licenses/by/4.0/), which permits unrestricted use, distribution, and reproduction in any medium, provided the original author and source are credited, a link to the CC License is provided, and changes - if any - are indicated. (SID_1) 